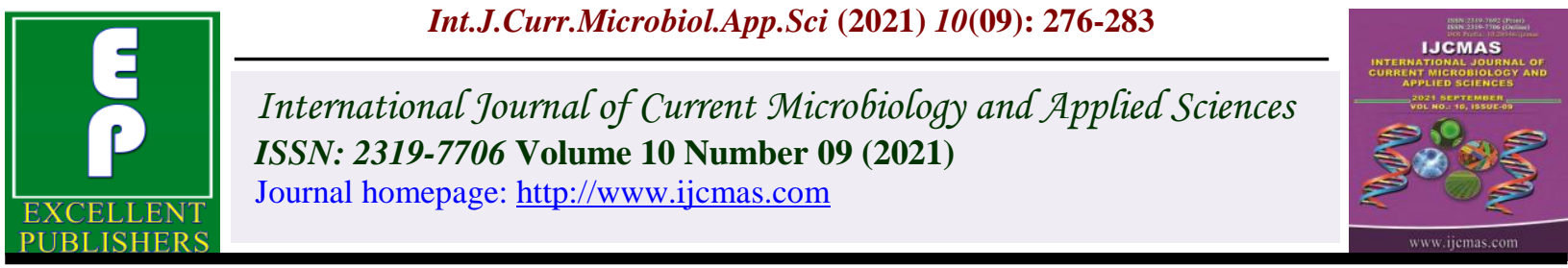

\title{
Assessment of Minerals, Vitamins, Amino and Fatty Acids Components of Pleurotus ostreatus Mushrooms Cultivated and Sold in the Village of M'Badon (Abidjan, Côte d'Ivoire)
}

\author{
Jacques Mankambou Gnanwa ${ }^{1,3^{*}}$, Lêniféré Chantal Soro², Jean Bedel Fagbohoun ${ }^{4}$, \\ Nourou S. Yorou ${ }^{5}$ and Lucien Patrice Kouame ${ }^{3}$
}

${ }^{1}$ Laboratoire d'Agrovalorisation de l'UFR Agroforesterie, Unité d'enseignement Biochimie, Microbiologie, Université Jean Lorougnon Guédé, BP 150 Daloa, Côte d'Ivoire

${ }^{2}$ UFR Ingénierie Agronomique Forestière et Environnementale de l'Université Polytechnique de Man, BP 20 MAN

${ }^{3}$ Laboratoire de Biocatalyse et de Bioprocédés, Université Nanguy Abrogoua, 02 BP801 Abidjan 02, Côte d'Ivoire.

${ }^{4}$ Laboratoire de Biochimie-Génétique, Université Peleforo Gon Coulibaly, Korhogo, Côte d'Ivoire.

${ }^{5}$ Faculté d'agronomie, Université de Parakou, Bénin

*Corresponding author

Keywords

Pleurotus ostreatus, mushrooms, nutrional characterisation, M'Badon village

Article Info

Accepted: 15 August 2021 Available Online: 10 September 2021
Mushroom cultivation has been started in Côte d'Ivoire. Awareness of the nutritional and medicinal importance of mushrooms is not extensive. In this study, the nutritional values of dietary mushrooms Pleurotus ostreatus, that are very popular among the cultivated mushrooms in Côte d'Ivoire have been determined. The samples were obtained and analysed for proximate, mineral, vitamin, amino acids and fatty on dry weight basis using standard methods. These mushrooms were rich in minerals content $(\mathrm{Cu}=36.35 \%$; Iron $=52.65 \%$; Magnesium $=47.84 \%$; Sodium $=14.50 \%)$ and contained a lower amount of calcium $(9.85 \%)$, phosphorus, potassium, and zinc. We also note the presence of vitamin A $(0.19 \%)$, vitamin $C(17.48 \%)$ and those of group B (B1, B2, B3, B6 and B9). The amino acids contents ranged from $1.17 \%$ for alanine and lysine, $1.7 \%$ for leucine and $0.07 \%$ to serine. The mushrooms are rich in lipid with the presence of linoleic acid, linolenic acid, oleic acid, palmitic acid and stearic acid. Data of this study suggest that mushrooms are rich in nutritional value. 


\section{Introduction}

Mushrooms are being recognised as important food items from ancient times. Their use is being increased day by day for their significant role in human health, nutrition and disease prevention.

They have been a widely used as food and food supplements for millennia (Chang, 1996). There is a common saying that "medicines and foods have a common origin" (Kaul, 2001; Kumari et al., 2014). Mushrooms provide a wide variety of medicinal properties and they are effective against certain life threatening diseases.

Major medicinal properties attributed to mushrooms include anticancer, antibiotic, antiviral activities, immunity and blood lipid lowering effects. Pleurotus spp. are also rich in medicinal values. These medicinal properties might be due to the presence of some important substance in mushrooms.

Thus, many studies reported that mushrooms are rich in protein, minerals and vitamins including dietary fibre and they contain an abundance of essential amino acids (Sadler, 2003; Kakon et al., 2012; Huang et al., 2015; Vishwakarma et al., 2017).

But nutritional values of locally cultivated mushrooms remain speculative. It should also be noted that the census studies of rare species carried out by (Marshall and Nair, 2009) and the work of (Flandroy, 1993) in no way aim at the biochemical, nutritional and microbiological aspect. Lack of knowledge of biochemical and nutritional characteristics is not for Pleurotus ostreatus a limiting factor in its popularisation? It is to this question that attempts to answer this work so the general objective is to contribute to the food security of the populations by the valorization of cultivated and marketed edible mushrooms.

\section{Materials and Methods}

\section{Biological material}

For the purposes of this study, the biological material (Figure 1) used in the analysis is the cultivated edible mushroom purchased at the market in the village of M'Badon (Abidjan, Lagoons, Côte d'Ivoire).

\section{Preparation of mushrooms Pleurotus ostreatus flour}

The mushroom samples were dried in the oven for 72 hours at $45^{\circ} \mathrm{C}$. They were then crushed in a MOULINEX brand blender to obtain a flour. These flours were kept in pots previously dried for possible analysis (Figure 2).

\section{Biochemical analysis}

\section{Minerals analysis}

Total ash was taken for the analysis of mineral contents. Two ml of conc. $\mathrm{HNO}_{3}$ was added to the ash and heated for 2 minutes. One drop of hydrogen peroxide was added into the solution. The solution was then transferred into a volumetric flask and total volume was made $50 \mathrm{ml}$ by adding deionized distilled water. This was then used to analyze the contents of magnesium (mg), zinc ( $\mathrm{Zn})$ and Copper $(\mathrm{Cu})$ by flame and graphite method with atomic absorption spectrophotometer (Perkin Elmer: AS 80)

Calcium (Ca) in ashed samples was determined by atomic absorption spectrophotometry after mineralization by hydrochloric acid (M.F.A., 1982).

Iron $(\mathrm{Fe})$ in ashed samples was estimated using a 1, 10- phenanthroline spectrophotometric method (M.F.A., 1982). Sodium (Na) and Potassium (K) were 
extracted from dried samples by acids before being determined with an atomic absorption spectrophotometer (M.F.A. 1982). Phosphorus (P) was determined spectrophotometrically after treating the ashed sample solution with ammonium molybdate, metavanadate and nitric acid (Gujral et al., 1987; M.F.A., 1982).

\section{Vitamin estimation}

The vitamin A content of mushroom flour was determined by dividing the $\beta$-carotene content by 12 (Borel et al., 2005). Folic acid (B9), thiamin (B1), riboflavin (B2), pyridoxine (B6) and niacin (B3) were estimated according to Kamman et al., (1980). Vitamin C was estimated by the 2, 6- dichloro phenolindophenol titration method (AOAC, 1995). Vitamin $\mathrm{E}$ was determined following a procedure previously optimized by Barros et al., (2008).

\section{Amino acid analysis}

Amino acid composition of mushroom sample was determined by using a high performance liquid chromatography (HPLC) based amino acid analysis.

To identify the amino acids after preparation of mushroom and standard solutions prepared, the samples were injected into HPLC Waters Alliance. The conditions of HPLC was determined as follows: column: $\mathrm{C} 18$ or equivalent, Wavelength of 254 nanometer, mobile phase (Methanol/Water (50:50)) and Flow Rate: $1.2 \mathrm{ml} \mathrm{min}^{-1}$.

\section{Fatty analysis}

To analyze fatty acids of samples, the HPLC chromatography method was used. The HPLC Waters Alliance Chromatography equipped with column $\mathrm{C} 18$ or equivalent, wavelength of $262 \mathrm{~nm}$, mobile phase (Methanol/Water (50:50)) and flow rate of $1.2 \mathrm{ml} \mathrm{min}^{-1}$.

\section{Statistic analysis}

All measurements were made in triplicate and the data presented are the averages of these three determinations + standard deviation. These data have been analysed variance (ANOVA) to test the effects of different experimental factors on the measured parameters. All these statistical analyses were carried out using Statistica 8.0 software.

\section{Results and Discussion}

Several nutritional parameters were measured for mushroom (Tables 1, 2, 3 and 4).

Mushrooms are rich in mineral contents. The total minerals content found in Pleurotus ostreatus, copper $(36.357 \pm 0.327 \%)$, iron $(52.653 \pm 0.061 \%)$ amd magnesium (47.840 \pm $1.126 \%$ ) (Table 1).

The results of the determination of the vitamins of Pleurotus ostreatus flour are given in Table 2. The vitamin contents of Pleurotus ostreatus flour are analysed with variable values. These are respectively $(0.1922 \pm 0.0206$ $\%)$ vitamin $A,(0.2978 \pm 0.0458 \%)$ thiamine, (2.7924 \pm 0.0076$)$ folic acid, $(5.0699 \pm 0.0006$ $\%)$ pyridoxine and $(17.4833 \pm 2.1605 \%)$ vitamin $\mathrm{C}$. We also have some traces of vitamin $\mathrm{E}$, riboflavin and niacin.

Table 3 shows the amino acid profile (\%) of $P$. ostreatus when grown and marketed in the village. Of the total 4 types of amino acids estimated, the alanine and lysine was 1.178 $\pm 0.007 \%$, leucine was $1.722 \pm 0.006 \%$ and serine $0.079 \pm 0.004 \%$ are in the least quantity.

Table 4 shows the fatty acid profile (\%) of $P$. ostreatus when grown and marketed in the village. Of the total 5 types of fatty acids estimated, the oleic acid (2.117 $\pm 0.008 \%)$, linoleic, linolenic palmitic and stearic acid 
were the value follow that $1 \%$. The result obtained from the biochemical analysis carried out on the mushroom Pleutorus ostreatus in this study confirmed that the minerals, vitamin, amino acid and fatty acid contents were found to be represented.

The mushrooms are reported to have a high level of well assimilated mineral elements. Major mineral elements in mushrooms are $\mathrm{Na}$, $\mathrm{Ca}, \mathrm{Cu}, \mathrm{Fe}, \mathrm{Mg}$ while trace elements like $\mathrm{P}, \mathrm{K}$, $\mathrm{Zn}$, are present as minor elements. The mineral proportions of mushrooms vary according to the species, age, the diameter of the fruiting body and substratum (Kakon et al., 2012). The low concentration of sodium and great amount of potassium suggest the use of mushroom as an anti-hypertensive diet (Manzi et al., 1999).

Minerals are essential for the growth, development, maintenance and repair of the body, the result of the minerals that were analysed shows that mushroom contain essential minerals that are essential constituents of skeletal structures such as bones and teeth. These minerals could play a key role in the maintenance of osmotic pressure, and thus regulate the exchange of water and solutes within the body, helps transmission of nerve impulses and muscle contraction and play a vital role in the acidbase equilibrium of the body thus regulate the $\mathrm{pH}$ of the blood and other body fluids (Kayode et al., 2013). Heavy metal contents of the mushroom were at relatively lower concentrations; which may make the mushrooms safe for consumption in accordance with the permissible tolerance limits of the estimated toxic metals. Therefore the result revealed that the samples are good sources of potassium (needed for glycogen and protein synthesis, and the metabolic breakdown of glucose), magnesium (activate various key enzyme systems, like kinases and is an essential component of bone, cartilage and the crustacean exoskeleton), iron (essential in transportation of oxygen and electron within the body), calcium (essential for absorption of vitamin B12 from the gastrointestinal tract) and phosphorous (important component of phospholipids, nucleic acids and many key enzymes which play important role in energy and cell metabolism) (Kayode et al., 2013). Sodium is relatively minimal in the sample thus may be good for patients with hypertension, mushroom are said to be good biological accumulators of zinc, and zinc is biologically very vital to the human body. From the values obtained, the sample could be a good source of zinc for human's need. Another mineral element found in the samples is copper which is believed to be necessary for the formation of the pigment melanin, bone and connective tissue, maintenance of the integrity of the myelin sheath of nerve fibers and consequently skin pigmentation (Kayode et al., 2013).

Mushrooms Pleurotus ostreatus are a good source of vitamins, especially rich in riboflavin, niacin and folates. They contain high amount of pyridoxine whose contents are of the same magnitude as that of vegetables. The bioavailability of the mushroom folates is good for folic acid unlike that of vegetables such as peas and spinach. In addition to riboflavin, niacin and folates, mushrooms also contain amounts of vitamin $\mathrm{C}$ and traces of vitamins B1, B2, B3, B9, vitamin E (Mattila et al., 2001).

Pleurotus ostreatus species is considered as a good source of protein. The protein of mushroom contains a number of amino acids, mainly alanine, leucine, lysine and serine (Guo et al., 2007; Manzi et al., 1999; Mdachi et al., 2004; Shah et al., 1997). Leucine is the most abundant essential amino acid in mushroom Pleurotus ostreatus. 
Table.1 Some minerals from Pleurotus ostreatus mushroom flour

\begin{tabular}{|c|c|}
\hline Composition & Values (\% DW) \\
\hline Calcium (Ca) & $9.857 \pm 0.311$ \\
\hline Copper (Cu) & $36.357 \pm 0.327$ \\
\hline Iron (Fe) & $52.653 \pm 0.061$ \\
\hline Magnesium (Mg) & $47.840 \pm 1.126$ \\
\hline Phosphorus (P) & $3.287 \pm 0.035$ \\
\hline Potassium (K) & $6.700 \pm 0.144$ \\
\hline Sodium (Na) & $14.503 \pm 0.072$ \\
\hline Zinc (Zn) & $5.460 \pm 0.082$ \\
\hline
\end{tabular}

Table.2 Some vitamins from Pleurotus ostreatus mushroom flour

\begin{tabular}{|c|c|}
\hline Composition & Values (\% DW) \\
\hline Vitamin A & $0.1922 \pm 0.0206$ \\
\hline Vitamin B1 & $0.2978 \pm 0.0458$ \\
\hline Vitamin B2 & $0.0286 \pm 0.0024$ \\
\hline Vitamin B3 & $0.1051 \pm 0.0008$ \\
\hline Vitamin B6 & $5.0699 \pm 0.0006$ \\
\hline Vitamin B9 & $2.7924 \pm 0.0076$ \\
\hline Vitamin C & $17.4833 \pm 2.1605$ \\
\hline Vitamin E & $0.1202 \pm 0.0007$ \\
\hline
\end{tabular}

Table.3 Some amino acids from Pleurotus ostreatus mushroom flour

\begin{tabular}{|c|c|}
\hline Parameters & Values $(\% \mathbf{D W})$ \\
\hline Alanine & $1.178 \pm 0.007$ \\
\hline Leucine* & $1.722 \pm 0.006$ \\
\hline Lysine* $^{*}$ & $1.175 \pm 0.001$ \\
\hline Serine & $0.079 \pm 0.004$ \\
\hline
\end{tabular}

Values are mean \pm standard deviation $(n=3)$

*Essential aminoacids

Table.4 Some fatty acids from Pleurotus ostreatus mushroom flour

\begin{tabular}{|c|c|}
\hline Parameters & Values (\% DW) \\
\hline Linoleic acid* & $1.857 \pm 0.004$ \\
\hline Linolenic acid & $1.209 \pm 0.002$ \\
\hline Oleic acid* & $2.117 \pm 0.008$ \\
\hline Palmitic acid & $1.104 \pm 0.003$ \\
\hline Stearic acid & $1.269 \pm 0.015$ \\
\hline
\end{tabular}

Values are mean \pm standard deviation $(\mathrm{n}=3)$

*Unsatured fatty acids 
Fig.1 Cultivated mushrooms Pleurotus ostreatus from M'Badon

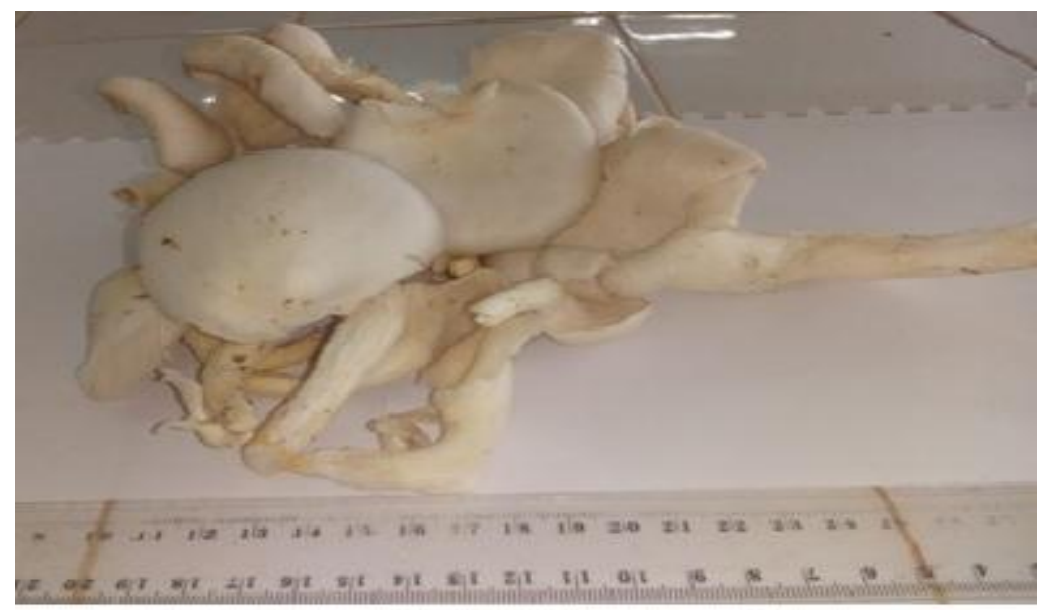

Fig.2 Flow diagram of the process for producing mushrooms Pleurotus ostreatus flour

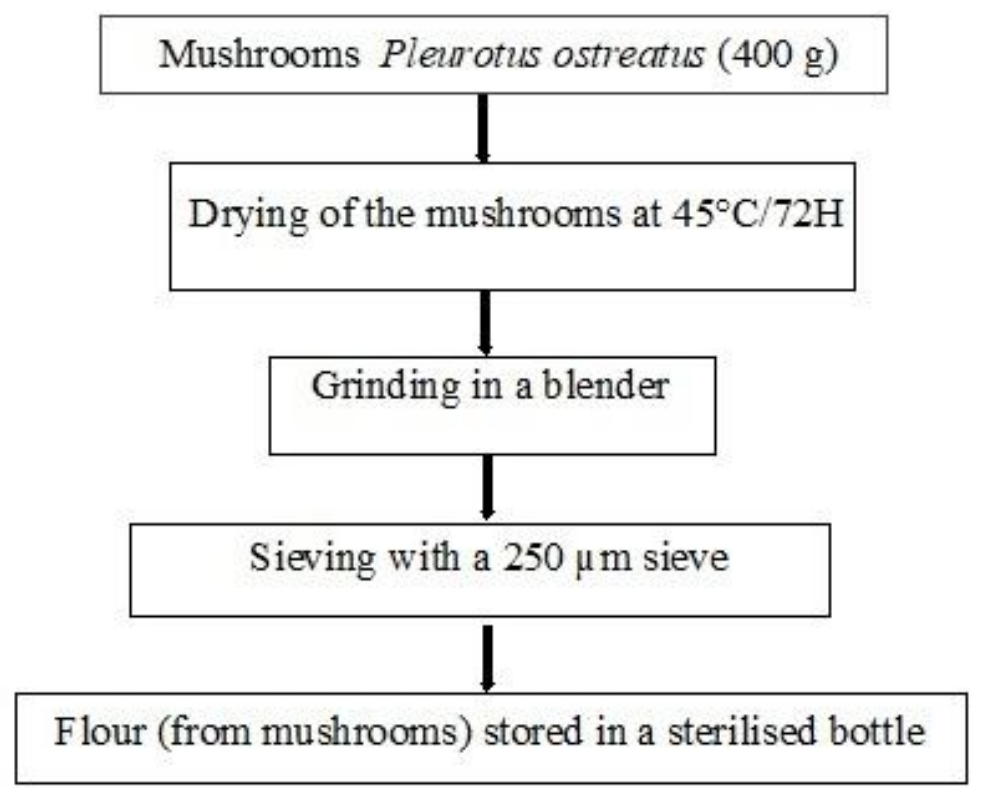

Generally, mushrooms have a low fat content. The range of fat content in mushrooms is 1.75 $-15.5 \%$ on a dry basis (Hong et al., 1988). The composition of fatty acid in many species of mushroom has been widely studied but for fatty acid composition in several stages of fungi has not been widely studied (Wang et al., 2001). The results of this research showed that the most dominant acids composition in mushrooms were oleic acid and linoleic acid. The both oleic and linoleicare unsaturated fatty acids which are considered to have a good nutritional value because it is more reactive and naturally antioxidants in the body (Kayode et al., 2013). This result is agree with those reported by Atri et al., (2013) and Maftoun et al., (2015). These authors reported in their broad compilation data of the nutritional composition in Pleurotus spp., that oleic acid (C18:1) was the major monounsaturated fatty acid while linoleic acid $(\mathrm{C} 18: 2 \mathrm{n}-6 \mathrm{c})$ was the major polyunsaturated 
fatty acid in Pleurotus species. The biochemical composition of edible mushrooms determines their nutritional value as also mentioned by other authors. Pleurotus ostreatus are rich in vitamin, amino acid, fatty acid and minerals. These results also indicate that the studied mushrooms have good nutritive value for human.

Pleurotus ostreatus flour may be recommended in the manufacture of infant and child foods. It could contribute to the fight against certain cardiovascular and nutritional diseases related to protein deficiencies, rich in mineral elements and contribute to a better conservation of flour.

\section{References}

AOAC.1995.Official methods of the analysis(16th ed.). Arlington, VA: Association of Official Analytical Chemists.

Atri, N., Sharma, S. K., Joshi, R., Gulati, A., and Gulati, A. 2013. Nutritional and nutraceutical composition of five culinary-medicinal species of genus Pleurotus (higher Basidiomycetes) from northwest India. International Journal of Medicinal Mushrooms, 15, 49-56.

Barros L., Baptista P., Correia D. M., Casal S., Olivera B. and Ferreira I. C. F. R. 2008. Fatty acid and sugar composition and nutritional value of five wild edible mushrooms from Northeast Portugal. Food Chem.105(1): 140-145.

Borel, P., Drai, J., Faure, H., Fayol, V., Galabert, C., Laromigulière, M. and Le Moel, G. 2005. Intestinal absortion and cleavage of carotenoids. Ann Bio Clin (Paris). 63(2) :165-77

Chang, S. T., and Buswell, J. A. 1996. Mushroom Nutriceuticals. World J. Microbiol. Biotechnology, 12: 473476.
Flandroy L. 1993. Savez- vous planter des champignons à la mode des chinois ? Biofutur $\mathrm{N}^{\circ} 123,38-43$.

Gujral, S. S., Bisaria, R., Madan, M., and Vasudevan, P.1987. Solid state fermentation of Saccharummunja residues into food through Pleurotus cultivation. J. Ferment. Technol. 65, 101-105.

Guo L. Q., Lin J. Y. and Lin J. F. 2007. Nonvolatile components of several novel species of edible fungi in China. Food Chem. 100(2): 643-649.

Hong J. S., Kim Y. H., Lee K. R., Kim M. K., Cho C. I. and Part K. K. H. 1988. Composition of organic abd fatty acid in Pleurotus ostreatus, Lentinus edodes and Agaricus bisporus. Korean J. Food Sci. Technol. 20: 100-105.

Huang, S-J., Lin, C-P., and Tsai, S-Y. 2015. Vitamin D2 content and antioxidant properties of fruit body and mycelia of edible mushrooms by UV-B irradiation. Journal of Food Composition and Analysis, 42, 38-45.

Kakon, A. J., Choudhury, M. B. K. and Saha, S. 2012. Mushroom is an Ideal Food Supplement. J. Dhaka National Med. Coll. Hos, 18(01): 5862.

Kamman, J. F., Wanthesen, J. J., and Labuza, T. P.1980. Technique for measuring thiamin and riboflavin in fortified foods. Journal of Food Science, 45, 1497-1499.

Kaul, T. N. 2001. Biology and Conservation of Mushrooms, pp.117-145. Oxford \& IBH Publishing Co. Pvt. Ltd. New Delhi, India.

Kayode, R. M. O., Olakulehin, T. F., Annongu, A. A., Sola-Ojo, F. E., Oyeyinka, S. A., and Kayode, B. I. 2013.Screening evaluation of the nutritional composition And phytochemical of an exotic and wild species of Oyster mushrooms (Pleurotus-sajor caju) Nigerian 
Journal of Agriculture, Food and Environment. 9(3):48-53

Kumari B., and Atri N S. 2014. Nutritional and nutraceutical potential of wild edible macrolepiotoid mushrooms of north India. International Journal of Pharmacy and Pharmaceutical Sciences 6 (2) : 200-204.

Maftoun, P., Johari, H., Soltani, M., Malik, R., Othman, N. Z., and El Enshasy, H. A. 2015. The Edible Mushroom Pleurotus spp.: I. Biodiversity and Nutritional Values. International Journal of Biotechnology for Wellness Industries, 4, 67-83.

Marshall E. and Nair G. 2009. Make money by growing mushrooms. Rome : FAO (Italie), Diversification booklet, $64 \mathrm{p}$.

Manzi, P., Gambelli, L., Marconi, S., Vivanti, V. and Pizzoferrato, L. 1999. Nutrients in edible mushrooms: an inter-species comparative study. Food Chemistry, 65: 477-482.

Mattila, P., Konko, K., Eurola, M., Pihlawa, J. M., Astola, J., Vahteristo, L.V., Kumpulainen, J.,Valtonen, M., and Piironen, V. 2001. Contents of vitamins, mineral elements, and phenolic compounds in cultivated mushrooms. J. Agric.Food Chem., 49:2343-2348.

Mdachi, S. J. M., Nkunya, M. H. H., Nyigo, V. A. and Urasa, I. T. 2004. Amino acid composition of some Tanzanian wild mushrooms. Food Chemistry, 86: $179-182$.

M. F. A. 1982. Methods of food analysis. NipponShokuhin Kogyo Gakkaishi, Tokyo.

Sadler, M. 2003. Nutritional properties of edible fungi. Br. Nutr.Found. Nutr. Bull. 28:305-308.

Shah, H., Iqtidar, A. K. and Shagufta, J. 1997. Nutritional composition and protein quality of Pleurotus mushroom. Sarhad J. Agric. 13:621-626.

Vishwakarma P, Singh P., and Tripathi N. N. 2017. In-vitro antioxidant activity and nutritional value of four wild oyster mushroom collected from NorthEastern Part of Uttar Pradesh. Mycosphere 8(4), 592-602

Wang, D., Sakoda, A., and Suzuki, M. 2001. Biological efficiency and nutritional value of Pleurotus ostreatus cultivated on spent beet grain. Bioresources technology. 78, 293-300.

\section{How to cite this article:}

Jacques Mankambou Gnanwa, Lêniféré Chantal Soro, Jean Bedel Fagbohoun, Nourou S. Yorou and Lucien Patrice Kouame. 2021. Assessment of Minerals, Vitamins, Amino and Fatty Acids Components of Pleurotus ostreatus Mushrooms Cultivated and Sold in the Village of M'Badon (Abidjan, Côte d'Ivoire). Int.J.Curr.Microbiol.App.Sci. 10(09): 276-283. doi: https://doi.org/10.20546/ijcmas.2021.1009.032 